\title{
Mangrove sponge disease induced by cyanobacterial symbionts: failure of a primitive immune system?
}

\author{
Klaus Rützler \\ Department of Invertebrate Zoology, National Museum of Natural History, Smithsonian Institution, \\ Washington, D. C. 20560, USA
}

\begin{abstract}
Cyanobacteria occurring in close intercellular association with sponges may at times multiply faster than the host is able to tolerate. The resulting disease is observed in Geodia papyracea, a 'bacteriosponge' from a mangrove island off Belize. G. papyracea has symbiotic coccoid bacteria equal in volume to nearly half of its own cellular tissue, but, unlike other sponges, it seems unable to control the quantity of the photosynthetic symbiont. Under favorable conditions, the cyanobacteria multiply faster than sponge archaeocytes can eliminate the excess and cause extrnsive histolysis in the host, possibly by toxic excretions. In response, the sponge establishes spongin barriers, sloughs off decaying tissue, and forms 'pseudogemmules' to expel cyanobacteria trapped inside archaeocytes.
\end{abstract}

\section{INTRODUCTION}

Diseases of sponges in natural environments are not well understood. Most studies describe the negative effects of environmental stress factors (Arndt 1928, Laubenfels 1950, Hartman 1958, Storr 1964, Reiswig 1971, Gerrodette \& Flechsig 1979, Fell in press), physical injury (Cheng et al. 1968b), and commensal or parasitic macroorganisms (Arndt 1933, Connes et al. 1971, Rützler 1975, Lauckner 1980, Lewis 1982). Less obvious causes of disorders, such as microbial agents, have remained highly speculative (Arndt 1928, Dosse 1940, Smith 1941, Lauckner 1980, Gaino \& Pronzato 1987), primarily because a diseased sponge is quickly infested by a diverse complement of bacteria and fungi, most of which are certainly not the cause of the malady. However, healthy sponges from tropical and subtropical marine shallow-water habitats are known to harbor bacteria (Vacelet \& Donadey 1977, Reiswig 1981), cyanobacteria (Wilkinson 1980, Rützler in press), and fungi (Höhnk \& Ulken 1979) as symbionts, which in some species can equal or exceed the hosts' tissue mass ('bacteriosponges') (Reiswig 1981). Although the impact of these associations on the sponge partner is not fully known, it is generally considered to be beneficial and of considerable trophic significance. This is the first report of a sponge disease in which extensive histolytic processes are linked to the presence of endobiotic cyanobacteria.

\section{MATERIAL AND METHODS}

The afflicted species is the tetractinellid demosponge Geodia papyracea Hechtel. This sponge grows on subtidal ( 0.2 to $1.0 \mathrm{~m}$ deep) stilt roots of red mangrove (Rhizophora mangle) bordering channels throughout Twin Cays $\left(16^{\circ} 49.4^{\prime} \mathrm{N}, 88^{\circ} 05.8^{\prime} \mathrm{W}\right)$, a Caribbean mangrove island off the coast of Belize, Central America. Twin Cays are part of the Belize barrier reef complex and site of a comprehensive mangrove community study under the auspices of the National Museum of Natural History (Washington, D. C.) (Rützler \& Feller 1988)

Inoculation tests were performed on cyanobacteriafree specimens abtained by cutting slices $(2 \mathrm{~cm}$ thick) perpendicular to the surface of large individuals and trimming off all greenish-brownish former near-surface tissue that contained the photosynthetic symbiont. These slices were tied to $12 \mathrm{~mm}$-mesh plastic grid by nylon monofilament line, and returned to the original collecting site for healing. After $5 \mathrm{~d}$, a new cortex had formed over the cut. After 10 d (February 1985), the clean (from cyanobacteria, as confirmed by light mi- 
croscopy) new surfaces were punctured and the inocula (cyanobacteria-rich tissue) implanted under the cortcx. Results were checked after 5 d, $78 \mathrm{~d}$ (May 1985), 1 yr (February 1986), and 1.3 yr (May 1986) exposure in the original habitat.

Microscope observations were either made on fresh material in the field or on specimens subjected to the following processing methods: Fixation in $1.5 \%$ glutaraldehyde in $0.2 \mathrm{M}$ cacodylate butter with $0.1 \mathrm{M}$ sodium chloride and $0.35 \mathrm{M}$ succrose, $\mathrm{pH} 7.2$ (2 to $4 \mathrm{~h}$, $29^{\circ} \mathrm{C}$ ). Postfixation in $1 \%$ osmic acid in the same buffer solution $\left(1 \mathrm{~h}, 4^{\circ} \mathrm{C}\right)$, buffer rinse and dehydration to $95 \%$ ethanol in 7 steps. Desilicification by $5 \%$ addition of hydrofluoric acid to the washing solution (buffer) before final rinse and dehydration. Material was stored in the last ( $95 \%$ ) ethanol stop for 1 wk, then dehydrated and embedded in Spurr low viscosity embedding media (Polysciences, Inc., USA) for transmission electron microscopy (TEM) or critical-point dried (liquid $\mathrm{CO}_{2}$ ) for scanning electron micoscopy (SEM). Sections (TEM) were stained with uranyl acetate and photograpped by a Zeiss EM9 S-2 microscope at 1900 to 28000 times primary magnification. SEM mounts were coated by $20 \mathrm{~nm}$ gold and photographed by a Hitachi SEM 570.

\section{RESULTS}

Specimens of Geodia papyracea are massive, lobate, and 10 to $15 \mathrm{~cm}$ in diameter on average. This species is easily identified by touching because its pulpy choanosome is covered by a brittle $0.5 \mathrm{~mm}$ thick cortex (Fig. 1) that feels like sandpaper. The color of the sponge surface changes with increasing light exposure, from cream to light gray or to dark brown. The choanosome is usually light cream, with greenish tinges near the cortex. Touching the dark brown areas of the live sponge in situ reveals extensive tissue decay because the papery cortex breaks and releases a cloud of muddy brownish material.

Microscope examination of healthy (cream, light gray, or light brown) Geodra papyracea reveais a dense fibrillar cortex reinforced by spherical silicious spicules (sterrasters) and supported by radial bundles of macroscleres (oxeas, plagiotriaenes) (Fig. 1). Below are lacunar spaces followed by a dense mesohyl containing sponge cells, spongin fibrils, and fibril bundles, spicules, and coccoid bacteria that constitute as much as half of the volume of cellular tissue (Fig. 2a, b). In brownish-pigmented specimens 2 to $10 \%$ of the bacteria in the outermost $10 \mathrm{~mm}$ of tissue are photosynthet-

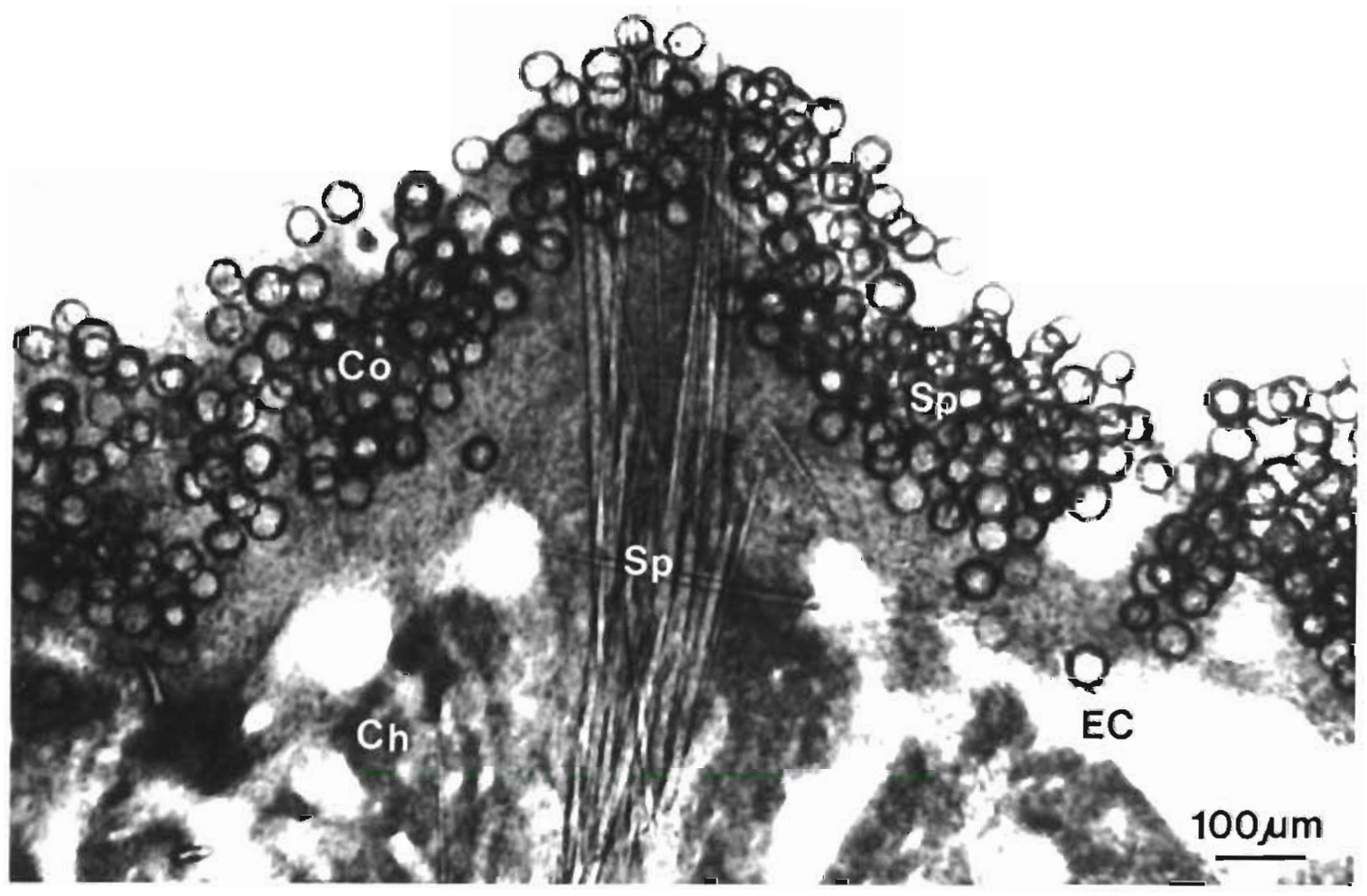

Fig. 1. Geodia papyracea. Anatomy in cross section. Ch: choanosome, Co: cortex, EC: exhalant canal, Sp: spicules 

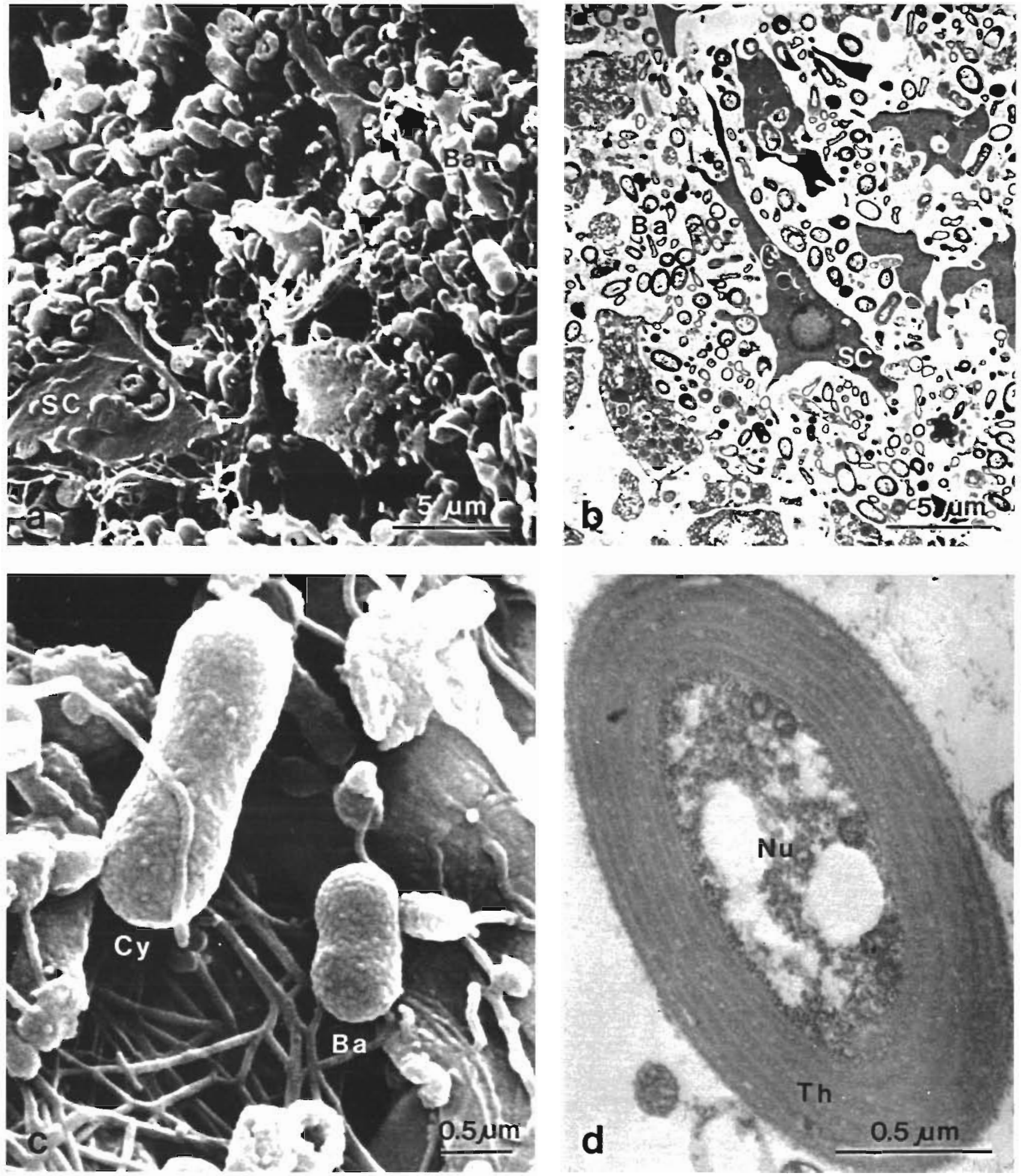

Fig. 2. Geodia papyracea. Histology. (a) Choanosome of healthy sponge with symbiotic bacteria (SEM). (b) Similar view (TEM). (c) Dividing stages of symbiotic cyanobacterium and bacterium (SEM). (d) Section through cyanobacteria symbiont. Ba: bacterium, Cy: cyanobacterium, Nu: nucleoplasm, SC: sponge cell, Th: thylakoid

ic cyanobacteria (Fig. 2c, d). The bacteria are oval, measure $1.4 \times 0.8 \mu \mathrm{m}$ on average, are Gram negative, and divide by median constriction perpendicular to the larger axis. The cyanobacteria have the same shape and figure- 8 dividing pattern as the bacteria but are larger $(2.2 \times 1.3 \mu \mathrm{m})$, possess a spiral ( 2 to 6 turns) 
thylakoid, and typical photosynthetic pigmentation. (chlorophyll a, phycobilins), although spectra differ from those published for similar organisms (Rützler, Gantt \& Lipschultz unpubl.).

Macroscopically, diseased zones on these sponges extend over 1 to $25 \mathrm{~cm}^{2}$ of the surface and are recognized by their yellowish to brownish color (very dark near and in the cortex) and histolysis. After removal of the cortex, loose, foul-smelling cellular material containing large quantities of cyanobacteria can be washed out by a gentle jet of water, leaving almost bare spicular columns and gemmule-like globules (Fig. $3 \mathrm{a}), 0.5$ to $2.0 \mathrm{~mm}$ in diameter, to a depth of $35 \mathrm{~mm}$ into the sponge choanosome. TEM examination of these globules shows that they are encased and traversed by thick (up to $8 \mu \mathrm{m}$ ) layers and strands of spongin microfibrils and filled with sponge archaeocytes, cyanobacteria, and a few bacteria. Most cyanobacteria occur inside sponge-cell vacuoles and in different stages of digestion (Fig. 4)

Attempts to culture the cyanobacteria on agar plates in the laboratory were unsuccessful; therefore no uncontamined isolates could be produced. Instead, mixed inocula had to be used to demonstrate the possible infectious nature of the suspected pathogen. These included the pseudogemmules mentioned above and $10 \mathrm{~mm}^{3}$ wads of yellow necrotic tissue (both rich in cyanobacteria). Controls consisted of healthy choanosomal tissue (containing bacteria but no cyanobacteria) of Geodia papyracea and freeliving filamentous mangrove c:anobacteria (Oscillatoria sp.). Test hosts were cyanobacteria-free G. papyracea (see methods section) originating from 2 specimens, one of them the donor of the inocula, and $G$. gibberosa Lamarck, a reef species never found with cyanobacteria. After $78 \mathrm{~d}$, inocula containing symbiotic cyanobacteria were absorbed by most surviving specimens of $G$. papyracea and appeared as brown patches. 8 to $14 \mathrm{~mm}$ in diameter (Fig. 3a, Tables 1 and 2). Only Oscillatoria sp. was rejected by this sponge. In the $G$. gibberosa controls, all implants were rejected. One year after the inoculation, all nine $78 \mathrm{~d}$ survivors of $G$. papyracea slices were still in place, had grown to almost double their original volume, and had assumed a uniform chestnut brown color without signs of the disease. Three months later (May), 5 of the remaining 7 specimens $(2$ had been sacrificed for histological study) showed symptoms of 'yellow decay' under dark brown patches of cortex.

Isolated pseudogemmules were maintained in fresh
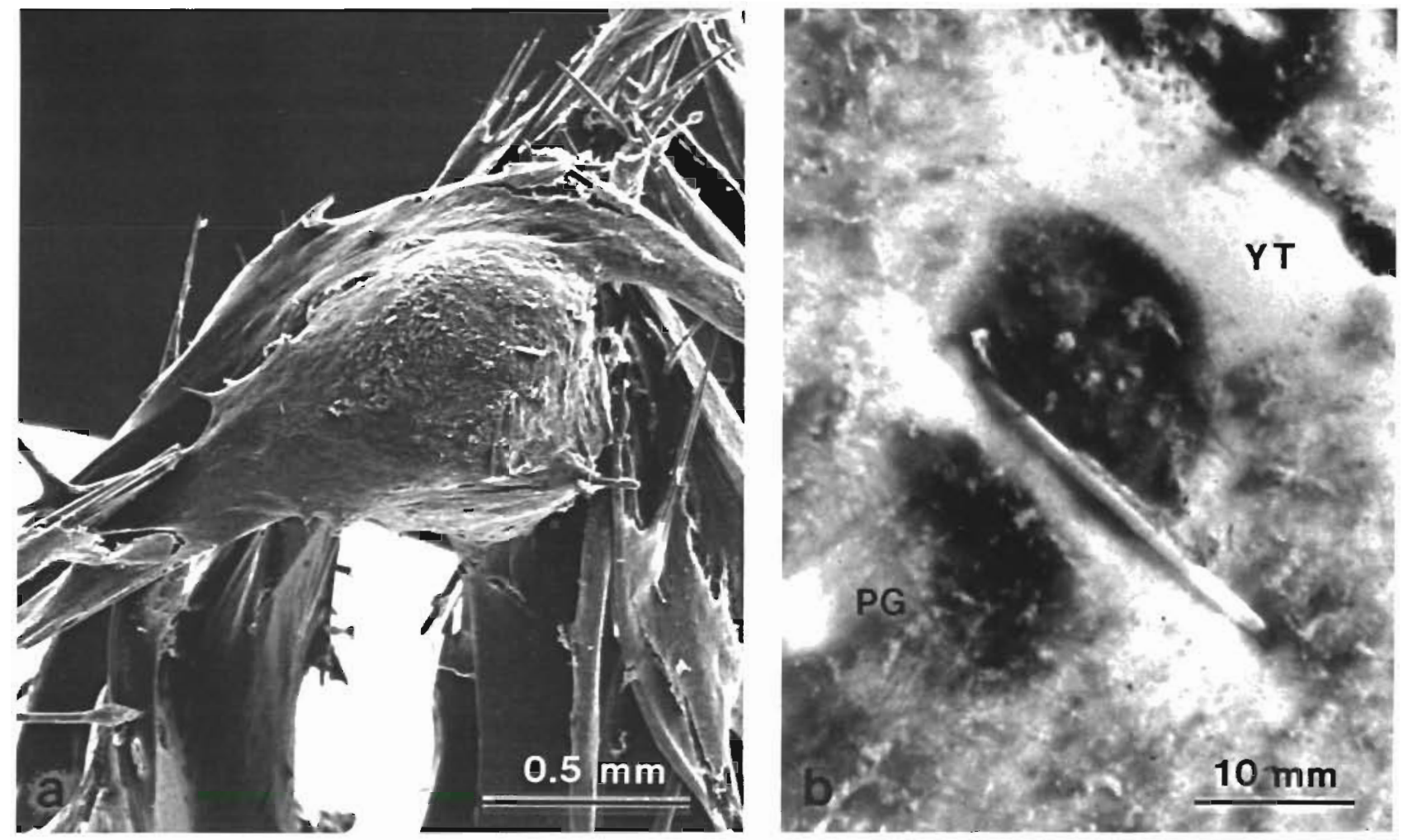

Fig. 3. Geodia papyracea. (a) Pseudogemmule still attached to sponge spicule-tissue strands; surrounding decayed tissue has been rinsed out (SEM). (b) Tissues plugs containing symbiotic cyanobacteria incorporated into freshly formed (symbiont free) $G$. papyracea cortex $78 \mathrm{~d}$ after inocculation. PG: pseudogemmule, YT: yellow tissue. Diagonal bar: piece of monofilament fishing line used to tie sponge slices to a support rack 

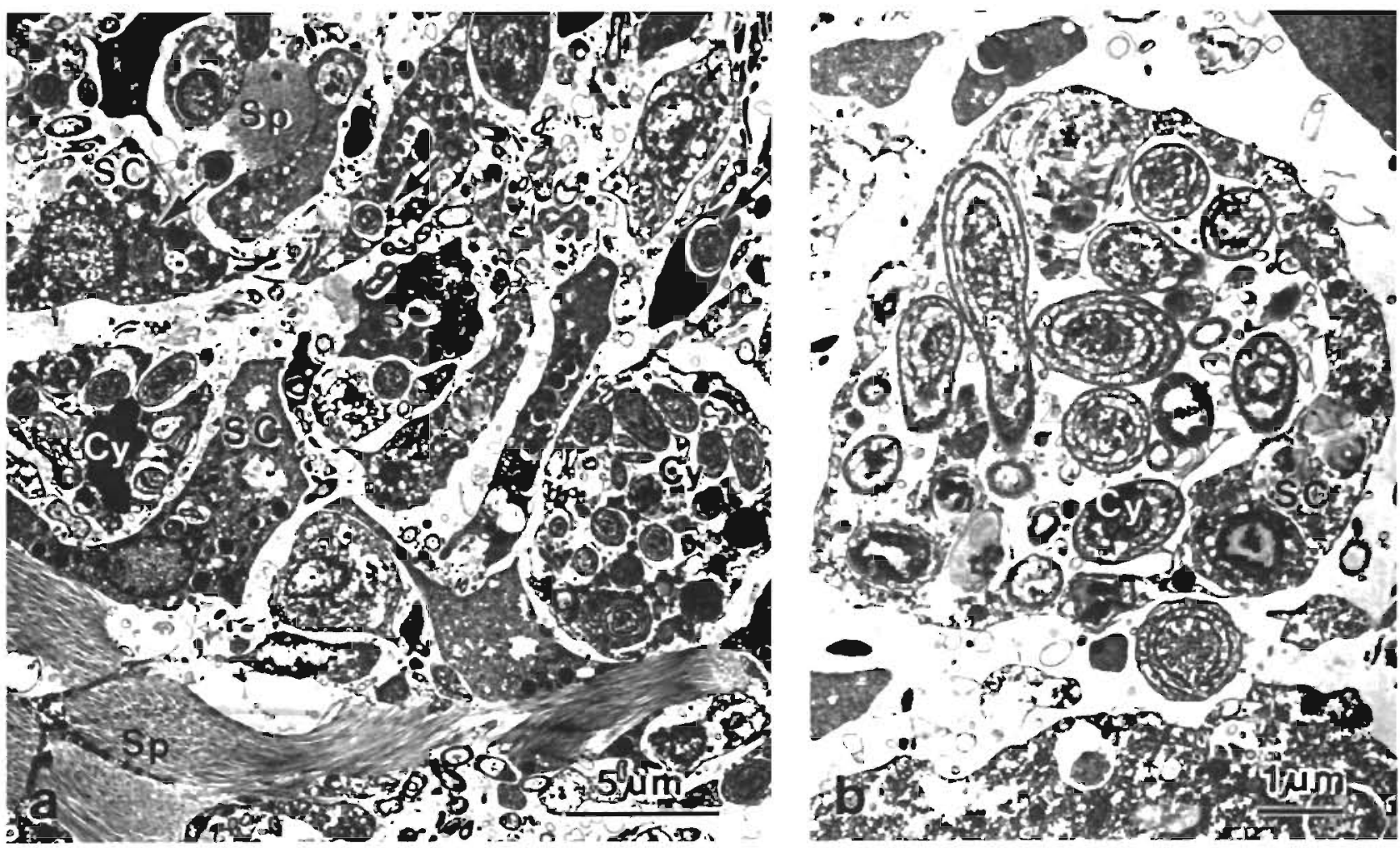

Fig. 4. Geodia papyracea. Concentration and phagocytosis of symbiotic cyanobacteria in diseased tissue zones (TEM). (a) Pseudogemmule. (b) Decomposing ectosome. Cy: cyanobacterium, SC: sponge cell (arrow indicating digestion of cyanobacterium), Sp spongin

seawater in the laboratory, running or changed once a day, to determine whether they would attach and form new sponges, as could be expected of typical sponge gemmules. No attachment was observed, although the sponge globules remained alive for $20 \mathrm{~d}$ in each of the 2 seasons monitored (February, June). On the other hand, when naturally diseased sponges in the field were freed of all necrotic tissue by cutting it away with a razor blade, they healed completely within 2 mo and slowly regained modest symbiont numbers from adjacent (nonexcised) cortex tissue during the following year.

\section{DISCUSSION}

The original systematic description of Geodia papyracea (Hechtel 1965) from mangroves in Jamaica mentions only off-white and light gray specimens, some with purple tinges. Although the soft consistency of the sponge is mentioned, apparently no discoloration or tissue decay were observed. Soft consistency is proper to all mangrove sponges and attributable to physicochemical conditions of the habitat water; other members of the genus are rock hard. The fact that sponges of one species may occur with or without cyanobacterial symbionts is well documented, but the association has always been considered beneficial to the sponge (Sarà 1964, Wilkinson 1980). Therefore the question of how sponges control the number of these symbionts has never been raised. One obvious possibility is phagocytosis. Past observations suggest that this process plays a central role in the removal of defective or damaged symbionts, but it has not been observed often enough to determine its trophic significance (Wilkinson 1980). However, nonsymbiotic bacteria and other intruders into sponge tissue are known to be eliminated by archaeocyte phagocytosis, often followed by the expulsion of these cells, and by the formation of collagen-like (spongin) barriers or capsules (Connes 1967, Cheng et al. 1968a, b, Van de Vyver 1980). At least one sponge (Tethya lyncurium) has been known to fight bacterial invasion by abandoning decaying body parts and by isolating clusters of unaffected multipotent cells (archaeocytes) that can reorganize tissues (Connes 1967).

Evidence gathered during this study indicates that Geodia papyracea lives in symbiosis with a unicellular 'Aphanocapsa feldmanni'-type cyanobacterium (Rützler in press) if illumination is sufficient for photosynthesis to occur inside the sponge tissue. If conditions become 'too favorable' for the endosymbiont, it multiplies faster than the host archeocytes are able to elimi- 
Table 1. Results of field inoculation experiment over time. Hosts are cuttings derived from 2 specimens of Geodia papyracea ( $G$. $p$. A. G. p. B) and from Geodia gibberosa (G. g.). Inocula were pseudogemmules, yellow (necrotic) tissue (both containing high levels of cyanobacteria), white (healthy, cyanobacteria free) tissue from G. p. A, and nonsymbiotic Oscillatoria. +: implant accepted; -: implant rejected (plug discolored and infected by Beggiatoa-like bacteria); ?: status inconclusive; 0: no result; x: experiment lost

\begin{tabular}{|c|c|c|c|c|c|c|c|c|c|}
\hline \multirow[t]{2}{*}{ No. } & \multirow[t]{2}{*}{ Host } & \multicolumn{4}{|c|}{ Implant status after $5 \mathrm{~d}$} & \multicolumn{4}{|c|}{ Implant status after $78 \mathrm{~d}$} \\
\hline & & $\begin{array}{l}\text { Pseudo- } \\
\text { gemmules }\end{array}$ & $\begin{array}{l}\text { Yellow } \\
\text { tissue }\end{array}$ & $\begin{array}{l}\text { White } \\
\text { tissue }\end{array}$ & $\begin{array}{c}\text { Oscilla } \\
\text { toria }\end{array}$ & $\begin{array}{l}\text { Pseudo- } \\
\text { gemmules }\end{array}$ & $\begin{array}{l}\text { Yellow } \\
\text { tissue }\end{array}$ & $\begin{array}{l}\text { White } \\
\text { tissue }\end{array}$ & $\begin{array}{c}\text { Oscilla- } \\
\text { toria }\end{array}$ \\
\hline 1 & G. p. A & + & + & + & ? & + & + & + & - \\
\hline 2 & G. p. A & ? & + & + & - & + & + & + & 0 \\
\hline 3 & G. p. A & + & + & + & - & $x$ & $\mathrm{x}$ & $\mathrm{x}$ & $\mathrm{x}$ \\
\hline 4 & G. p. A & + & + & + & - & + & + & + & 0 \\
\hline 5 & G. p.A & + & + & + & - & + & + & + & 0 \\
\hline 6 & G. p. A & + & + & + & - & + & + & + & 0 \\
\hline 7 & G.p. A & + & $?$ & $?$ & - & $\mathrm{x}$ & $\mathrm{x}$ & $\mathrm{x}$ & $\mathrm{x}$ \\
\hline 8 & G. p. A & + & $?$ & + & - & + & $?$ & + & 0 \\
\hline 9 & G.p. B & + & $?$ & + & $?$ & + & $?$ & $i$ & - \\
\hline 10 & $G \cdot p \cdot B$ & $?$ & + & + & - & $?$ & + & + & 0 \\
\hline 11 & G.p. B & $?$ & + & + & - & $\mathrm{x}$ & $\mathrm{x}$ & $\mathrm{x}$ & $x$ \\
\hline 12 & G. p. B & + & + & $?$ & - & + & + & $?$ & 0 \\
\hline 13 & $G . g$. & - & - & - & - & 0 & 0 & 0 & 0 \\
\hline 14 & G. $g$. & - & - & - & - & 0 & 0 & 0 & 0 \\
\hline 15 & G. $g$. & - & - & - & - & 0 & 0 & 0 & 0 \\
\hline 16 & G. $g$. & - & - & - & - & 0 & 0 & 0 & 0 \\
\hline
\end{tabular}

Table 2. Success of field inoculations (percentage of implants clearly accepted). Changes in number of observations ( $n$ ) between scoring periods are due to losses of host specimens (see Table 1)

\begin{tabular}{|c|c|c|c|c|c|c|c|c|c|c|}
\hline \multirow[t]{2}{*}{ Host } & \multicolumn{5}{|c|}{ Success $(\%)$ after $5 \mathrm{~d}$} & \multicolumn{5}{|c|}{ Success $(\%)$ after $78 \mathrm{~d}$} \\
\hline & $\begin{array}{l}\text { Pseudo- } \\
\text { gemmules }\end{array}$ & $\begin{array}{l}\text { Yellow } \\
\text { tissue }\end{array}$ & $\begin{array}{l}\text { White } \\
\text { tissue }\end{array}$ & $\begin{array}{c}\text { Oscilla- } \\
\text { toria }\end{array}$ & $n$ & $\begin{array}{l}\text { Pseudo- } \\
\text { gemmules }\end{array}$ & $\begin{array}{l}\text { Yellow } \\
\text { tissue }\end{array}$ & $\begin{array}{l}\text { White } \\
\text { tissue }\end{array}$ & $\begin{array}{c}\text { Oscilla- } \\
\text { toria }\end{array}$ & $n$ \\
\hline Geodia papyracea A & 88 & 75 & 88 & 0 & 8 & 100 & 83 & 100 & 0 & 6 \\
\hline G. papyracea B & 50 & 75 & 75 & 0 & 4 & 67 & 67 & 67 & 0 & 3 \\
\hline G. gibberosa & 0 & 0 & 0 & 0 & 4 & 0 & 0 & 0 & 0 & 4 \\
\hline
\end{tabular}

nate the excess. This process may be accelerated or enhanced by periodic environmental stress conditions, such as excessive water warming, which are common in the mangrove habitat. High concentrations of cyanobacteria may become toxic to the host tissue, as has also been postulated for reef corals infected by the black band disease (Rützler et al. 1983). The sponge reacts by creating spongin barriers and by encapsulating concentrations of archaeocytes and cyanobacteria, a mechanism possibly comparable to granuloma formation in vertebrates. These 'pseudogemmules' are discharged as soon as the decomposing sponge cortex breaks. It is not known whether archaeocytes inside free pseudogemmules are eventually able to control the symbionts and generate new sponges.

Despite the benign nature of early stages in the symbiosis between Geodia and cyanobacteria this association lacks ecological equilibrium (Kinne 1980) and eventually turns into a disease at the expense of the sponge. The possibility exists, however, as sug- gested by Jeon (1987), that we are witnessing a newly evolving mutualistic relationship in which the sponge host has not yet developed physiological mechanisms to control a balanced coexistence with its cyanobacterial symbionts.

Acknowledgements. I thank P. Riordan for TEM sectioning, $\mathrm{H}$ Wolf for operating the SEM, and $\mathrm{K}$. Smith for darkroom work I. G. and V Macintyre, J. C. Harshbarger, and E. C. Peters made valuable comments on the manuscript. This is contribution no. 233, Caribbean Coral Reef Ecosystems (CCRE) program, National Museum of Natural History, Washington, D. C., partly supported by the Exxon Corporation

\section{LITERATURE CITED}

Arndt, W (1928). Lebensdauer, Altern und Tod der Schwämme. Sitz. Ber. Ges. Naturf. Fr Berlin 1928: 23-24 Arndt, W. (1933). Die biologischen Beziehungen zwischen Schwämmen und Krebsen. Mitt. zool. Mus. Berlin 19: $221-305$ 
Cheng, T C., Rifkin, E., Yee, H. W. F. (1968a). Studies on the internal defense mechanisms of sponges II. Phagocytosis and elimination of india ink and carmine particles by certain parenchymal cells of Terpios zeteki. Invertebr. Pathol. 11: 302-309

Cheng, T C., Yee, H. W. F., Rifkın, E., Kramer, M. D. (1968b). Studies on the internal defense mechanisms of sponges III Cellular reactions in Terpios zeteki to implanted heterologous biological materials. J. Invertebr. Pathol. 11: 29-35

Connes, R. (1967). Réactions de défense de l'éponge Tethya lyncurium Lamarck, vis-à-vis des micro-organismes et de l'amphipode Leucothoe spinicarpa Abbildg. Vie Milieu (Series A) 18: 281-298

Connes, R., Paris, J., Sube, J. (1971). Reactions tissulaires de quelques demosponges vis-à-vis de leurs commensaux et parasites. Naturaliste can. 98: 923-935

Dosse, G. (1940). Bakterien und Pilzbefunde sowie pathologische und Fäulnisvorgänge in Meeres- und Süßwasserschwämmen. Untersuchungen im Zusammenhang mit dem gegenwärtigen Sterben der Badeschwämme in Westindien. Z. ParasitKde 11: 331-356

Fell, P. E. (in press). Tolerances of the dormant forms of some estuarine sponges with emphasis on Microciona prolifera In: Rützler, K., Hartman, W. D. (eds.) New perspectives of sponge biology. Smithsonian Institution Press, Washington, D. C.

Gaino, E., Pronzato, R. (1987). Ultrastructural observations of the reaction of Chondrilla nucula (Porifera, Demospongiae) to bacterial invasion during degenerative processes. Cah. Biol. mar. 28: $37-46$

Gerrodette, T., Flechsing, A. O. (1979). Sediment-induced reduction in the pumping rate of the tropical sponge Verongia lacunosa. Mar. Biol. 55: 103-110

Hartman, W. D. (1958). Natural history of the marine sponges of southern New England. Peabody Mus. Nat. Hist., Bull. 12: $1-155$

Hechtel, G. J. (1965). A systematic study of the Demospongiae of Port Royal, Jamaica. Bull. Peabody Mus. nat. Hist. 20: $1-94$

Höhnk, W., Ulken, A. (1979). Pilze aus marinen Schwämmen. Veröff. Inst. Meeresforsch. Bremerhaven 17: 199-204

Jeon, K. W (1987). Change of cellular 'pathogens' into required cell components. In: Lee, J. J., Fredrick, J. F (eds.) Endocytobiology III. Ann. N. Y Acad. Sci. 503: 359-371
Kinne, O. (1980). Diseases of marine animals general aspects In: Kinne, O. (ed.) Diseases of marine animals, Vol. I. John Wiley and Sons, New York, p. 13-73

Laubenfels, N. W de (1950). An ecological discussion of the sponges of Bermuda. Trans. zool. Soc. Lond. 27: 155-201

Lauckner, G. (1980). Diseases of Porifera. In: Kinne, O. (ed.) Diseases of marine animals, Vol. I. John Wiley and Sons, New York, p. 139-165

Lewis, S. M. (1982). Sponge-zoanthid associations: functional interations. Smithson. Contr mar Sci. 12: 465-474

Reiswig, H. M. (1971). In situ pumping activities of tropical Demospongiae. Mar Biol. 9: 38-50

Reiswig, H. M. (1981). Partial carbon and energy budgets of the bacteriosponge Verongia fistularis (Porifera: Demospongiae) in Barbados. P.S.Z.N. Mar. Ecol. 2: 273-293

Rützler, K (1975). Ecology of Tunisian commercial sponges. Tethys 7: 249-264

Rützler, K. (in press). Associations between Caribbean sponges and photosynthetic organisms. In: Rützler, K. Hartman, W. D. (eds.) New perspectives of sponge biology. Smithsonian Institution Press, Washington, D. C

Rützler, K., Feller, C. (1988). Mangrove swamp communities. Oceanus 30(4): 16-24

Rützler, K., Santavy, D. L., Antonius, A. (1983). The black band disease of Atlantic reef corals III. Distribution, ecology, and development. P.S.Z.N. Mar. Ecol. 4: 329-358

Sarà, M. (1964). Simbiosi fra alghe unicellulari e invertebrati marini. Atti Seminario Studi Biologica (Bari) 1: 1-24

Smith, F. G. W (1941). Sponge disease in British Honduras, and its transmission by water currents. Ecology 22: 415-421

Storr, J. F. (1964). Ecology of the Gulf of Mexico commerical sponges and its relation to the fishery. U.S. Fish and Wildlife Service, Special Scientific Report, Fisheries No. 466: $1-73$

Vacelet, J., Donadey, C. (1977). Electron microscope study of the association between some sponges and bacteria. $J$. exp. mar. Biol. Ecol. 30: 301-314

Van de Vyver, G. (1980). Second-set allograft rejection in two sponge species and the problem of an alloimmune memory. In: Manning, M. J. (ed.) Phylogeny of immunological memory. Elsevier, New York, p. 15-26

Wilkinson, C. R. (1980). Cyanobacteria symbiotic in marine sponges. In: Schwemmler, W., Schenk, H. E. A. (eds.) Walter de Gruyter \& Co., New York, p. 553-563 